\title{
THE EFFECTS OF INTERNAL MARKETING ON ORGANIZATIONAL TRUST: A RESEARCHIN HOTEL INDUSTRY
}

\author{
Mustafa KESEN ${ }^{1}$ \\ Pinar Mutlu TURAN² \\ Naciye KUTA Y3
}

\author{
Received Date (Başvuru Tarihi): 16/10/2017 \\ Accepted Date (Kabul Tarihi): 21/12/2017 \\ Published Date (Yayın Tarihi): 07/01/2018
}

\begin{abstract}
The aim of this study is to determine how internal marketing would affect trust in the organization and trust in the executive dimensions of organizational trust. The study population consists of employees working in hotels operating in the town of Kuşadası in the province of Aydin, one of the oldest touristic regions of Turkey. For this purpose, a survey application was carried out on 148 employees of 7 hotels in total. The acquired survey data was evaluated via confirmatory factor analyses, reliability analyses, correlation analyses and regression analyses. According to the findings obtained from the research, internal marketing affects trust in the manager and trust in the organization positively. Despite some limitations, the research findings are consid ered to present some important assistance to the managers, employees and researchers.
\end{abstract}

Keywords: Internal Marketing, Organizational Trust, Hotel Industry

Jel Codes: D23, O15, J24

\section{İÇSEL PAZARLAMANIN ÖRGÜTSEL GÜVEN ÜZERINDEKİ ETKILERİ: OTEL İŞLTMELERINDE BİR ARAŞTIRMA}

\section{ÖZ}

Bu çalışmanın amacı içsel pazarlamanın örgütsel güvenin örgüte güven ve yöneticiye güven boyutlarını nasıl etkilediğini belirlemektir. Araştırma evrenini Türkiye'nin turistik bölgelerinden Aydın ilindeki Kuşadast ilçesinde faaliyet gösteren otellerin çalışanları oluşturmaktadır. Bu amaçla 7 otelin toplamda 148 çalışanı üzerinde anket uygulaması yapılmıştır. Elde edilen anket verileri doğrulayıcı faktör analizleri, güvenirlik analizleri, korelasyon analizi ve regresyon analizleri aracılĭ̆ bulgulara göre içsel pazarlama yöneticiye güveni ve örgüte güveni pozitif yönde etkilemektedir. Araştırma bulgularının, bazı sınırlılıklara rağmen yöneticilere, çalışanlara ve araştırmacılara önemli ipuçları sunacağı düşünülmektedir.

Anahtar Kelimeler: İçsel Pazarlama, Örgütsel Güven, Otelcilik Sektörü

Jel Kodlart: D23, O15, J24

\footnotetext{
${ }^{1}$ Assistant Professor, Adnan Menderes University, m kesen@ hotmail.com

2 Dr., pinarmutlu@gmail.com

${ }^{3}$ Kuşadası Municipality, kutaynaciye@yandex.com
}

http://orcid.org/0000-0003-1907-7748

http://orcid.org/0000-0002-1854-9363

http://orcid.org/0000-0003-1670-6270 


\section{INTRODUCTION}

Trust which forms one dimension of our social life can also be described as the key to a healthy business life. The trust that the employees feel towards each other is very important for the flow of work in organizations particularly where a group of people are in the position to realize various activities and work in cooperation for the sake of reaching a common goal. The feeling of trust in an individual in line with a certain topic, target or benefit is a phenomenon that needs to exist to be able to reach both the department and enterprise targets.

Organizations gain a personality in line with all the internal and external factors that constitute and affect them. Each organization has different organizational structures and working styles as each tries to exist in a different environment for the purpose of producing a different product or service. Therefore, each organization has a unique personality that makes it different than the others. When organizations are considered to gain a personality just like individuals, it is understood that trust towards the organizations are formed like that towards the individuals.

Trust is not a concept that automatically arises in organizations. To form an environment of trust, important roles are delegated to the stakeholders such as executives, employees, strategic partners etc. Especially the attitude and behaviors of executives, their decision styles, organizational practices regarding organizational culture and human resources formed by the executives affect the perception of trust directly. Internal marketing concept, which states that the employees are required to be satisfied like customers, will also play an important role in the trust perception of the organization's employees. It is much more probable that trust would be higher in those organizations where internal marketing activities are positively perceived. Thus, İçli and Aslan (2012: 41) point out that encouraging the employees to trust each other is one of the purposes of internal marketing activities. Similarly, Hume and Hume (2015) express in their studies that an environment of trust among the employees might be secured via internal marketing.

In this study internal marketing-organizational trust relation, a topic that was not encountered in literature, is analyzed with an applied study in the hospitality sector. In this context, the purpose of this study is to contribute to the organizational trust literature and propose internal marketing as a tool to increase organizational trust. First, a literature review concerning the topic was made in the research, then the design of the study, the application and the analysis of survey data phases were tackled and finally the results were interpreted. It is 
foreseen that the findings obtained would present important assistance to hotel executives, researchers, employees, other related people and organizations.

\section{CONCEPTUAL FRAMEWORK}

\subsection{Internal Marketing}

It is necessary to make changes not only in accounting, public relations, marketing and information systems but also in human resources management practices to be able to have customer-oriented organizational structures. To that end, concepts such as internal marketing that will form a basis for interdisciplinary research are required (Ay and Kartal, 2003:17).

The concept of internal marketing which is first mentioned in written sources by Berry et al. (1976) and George (1977) was defined by Berry and Parasuraman (1991:151) as "attracting, developing, motivating and retaining qualified employees through job-products that satisfy their needs." According to Kelemen and Papasolomou-Douk is (2004) internal marketing is the harmonization and integration of those theories, methods and rules regarding marketing and human resources to satisfy external customers.

When the development of the concept of internal marketing is examined, three separate phases interconnected to each other might be mentioned. These are; the employee satisfaction phase, customer-orientation phase and strategy application/change management phase. These development phases can be explained as follows (Rafiq and Pervaiz, 2000:448): In the employee satisfaction phase, the employee motivation and satisfaction form the focus point of related studies regarding internal marketing. The organization needs to have satisfied employees to be able to have satisfied customers. Sasser and Arbeit (1976) believe that the most important market of a service business is primarily its employees. In the second phase the purpose of internal marketing is to encourage employees to become customer-oriented. As for the last phase that is strategy application/change management phase, it is required to motivate the employees via directing, training them in line with the purposes of the business. Besides, internal marketing is considered as the structure that decreases the discrimination and conflicts between departments and that overcomes resistance to change (Odabaşı, 1995:32).

As per internal marketing concept, executives should make the employees feel that they take the employees and their needs into consideration. Some of the purposes of internal marketing are to have customer-oriented employees targeting to realize the corporate aims in each department of the organization, to attract and retain the personnel working towards this aim and to provide the permanency of skilled personnel. Likewise, determining a common 
target for all employees, thereby embracing a common course of action, creating an attractive company brand both from the point of consumers and the organization members are the targets of internal marketing activities (Yapraklı and Özer, 2002:59).

It is necessary to view the expenditure as an investment to reach success in internal marketing. Particularly the return on investment on the employees via education will be far more. It is required to pave the way for employees, to gain team spirit in work groups, to develop a reward system focusing on customer satisfaction and to allow two-way flow of information for employees to be able to make suggestions (Gülşen, 2010:44).

There are some significant points to take into consideration in internal marketing as it concerns both marketing and human resources departments. The coordination that is provided between these two departments will provide the business success to grow even more. On the other hand while external marketing has a direct profit generating feature, it is possible to say that internal marketing indirectly provides profit (Kalyoncu, 2007:83).

\subsection{Organizational Trust}

Trust can be expressed as someone having a positive expectation towards someone else and showing a psychological sensitivity regarding this expectation. According to Hosmer (1995), the expectations regarding an individual, group or organization to make the right decisions morally and develop behaviors depending on ethical principles are called trust. Organizational trust, on the other hand, is the perception of an employee on organizational support, his/her belief in his/her manager's being right and keeping his/her promise (Mishra and Morissey, 1990). Organizational trust is a phenomenon that is affected by those rules, values, beliefs, perceptions, feelings and behaviors dominant in the organization and that forms the basis of intra-organization communication (Özkalp and Kirel, 2010:76). In a nutshell organizational trust involves believing that no harm would come from other individuals, groups, institutions or organizations.

Organizational trust exists both on individual and organizational level. On the individual level, the trust feeling develops depending on the personal characteristics of employees and those events that they go through in their interpersonal relations. On the organizational level however, trust in the personality of the organization is meant and it develops depending on the culture of organization (Kırbaşlar, 2013:45).

Bromiley and Cummings (1996) evaluated trust as those common beliefs of an individual or a group in other individual or individual groups. They further stated that trust 
brought together explicitly or secretly the attempts to have a good faith in somebody, being honest, not expecting to exert advantage over the others even when the conditions permitted. One of the main determinants concerning trust is the expectations of the individual wishing to feel trust and those responses s/he gets in return to these expectations. Those organizations which take their employee's expectations into consideration and meet these expectations as much as possible have a much higher chance to have employees with high trust.

Organizational trust has three sub-dimensions. These are trust in the organization, trust in the executive and trust in the colleagues. Trust in the organization can be expressed as the positive expectations of the organization members on the intentions and behaviors of individuals depending on organizational roles, relations and experiences (Demircan and Ceylan, 2003:142). Trust in the executive was defined by Reinke and Baldwin (2001:164) as the belief of the employee that the executive would keep his/her promises, would act fairly and would give honest and correct answers. Executives have a rather important role in terms of helping the employees to feel trust in the organization and setting up positive relations with them. As employees perceive the executives as people representing the organization, when they feel trust in the executive, they might apply this throughout the whole organization. Executives might be building or destroying the trust environment with whatever they do or apply in the organization (Tüzün, 2007:107). It is due to this reason that it has been remarked by various researchers that trust is a process which needs to be started by executives (Uslu, 2013:26). Trust in the colleagues, on the other hand, expresses the belief regarding the individual would not be harmed by the attitudes and behaviors of the other party. In other terms, trust in the colleagues involves the assistance of each party to another when necessary, taking into consideration each other's benefits and their being open and honest with each other.

In those organizations where the level of trust is high, it is possible that the employees accept organizational change more easily and adapt to executive decisions. The level of organizational trust being high makes it easy for the employees to adapt to the structure of the organization and to the processes. It is expected from employees who trust in their colleagues, executives and organization to be satisfied with their jobs, to be loyal to their jobs and to show a high performance. It is stated as well that organizational trust develops the social relations between individuals, that an emotional bond is formed especially between those employees and the executives acting honestly and openly (Ylmaz and Atalay, 2009:347). 


\subsection{Research Model and Hypotheses}

Trust is formed depending on time through the interaction of intra-organizational elements and increases as more positive outputs are obtained at the workplace (Nevin, 1995). The working climate which depends on mutual trust, respect and friendship is affected directly by those decisions taken by the executives of the organization and those practices carried out (Johnston et al., 1990). It is expressed that in those work environments that allow access to information and sources, that support the employees and provide the development of employees, organizational trust increases (Kanter, 1993). The study of $\mathrm{Ng}$ et al. (2016) has highlighted support for trust as being influential to the effectiveness of internal marketing. Hume and Hume (2015) remark in their studies that an environment of trust in non-profitorganizations to reach success under knowledge management might be provided among employees via internal marketing. Similarly, Scovotti and Peltier (2005) mention that the way to increase organizational trust goes through building strong internal marketing relationships.

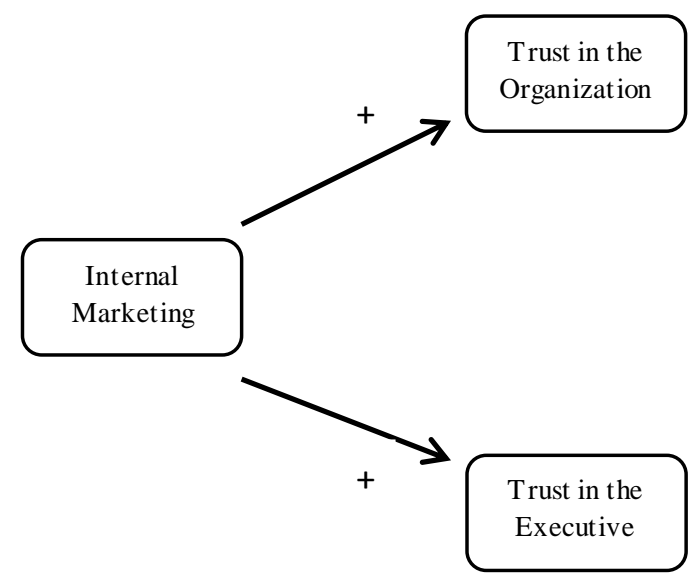

Figure 1: Research Model

Under the light of this information it can be expressed that the internal marketing activities would increase the trust of employees in both their organizations and in their executives. The research model of the study that is developed on the basis of these potential relationships is shown in Figure 1. The two hypotheses that are developed are as follows:

Hypothesis 1: Internal marketing affects trust in the organization positively.

Hypothesis 2: Internal marketing affects trust in the executive positively. 


\subsection{The Objective, Scope and Method of Research}

The aim of this study is to determine how internal marketing affects the trust in organization and trust in executive dimensions of organizational trust. The universe of research consists of those hotel employees operating in the town of Kuşadası in the province of Aydin, one of the oldest touristic regions of Turkey ${ }^{3}$. Within this scope, a survey was conducted on 148 employees in a total of 7 hotels via simple random sampling method in December, 2016.

Literature review was made to form the scales to be used in the survey and those scales with validity and reliability approved in Turkish language were chosen. The evaluation options belonging to related expressions in the survey are as follows: 1) I definitely do not agree, 2) I do not agree, 3) I am indecisive, 4) I agree, 5) I definitely agree.

The questionnaire forms used in the study consist of 2 sections. In the first part of the form, expressions useful to measure the internal marketing structure of businesses and organizational trust perceptions of employees are given. In the second part those expressions on the demographic structure of participants are found. The Turkish form of the internal marketing scale developed by Foreman and Money (1995) was taken from the study of Kaçaroğlu (2015). The organizational trust scale developed by Nyhan and Marlowe (1997) from Üstün (2015)'s study was taken. The internal marketing scale evaluated as one factor consists of 15 items while the trust in organization dimension of organizational trust consists of 4 and that of trust in executive consists of 8 items.

Data obtained from surveys analyzed with SPSS (Software Package for Social Sciences) and AMOS (Analysis of Moment Structures) software programs. In order to test the factorial validity, measurement models were tested by using confirmatory factor analyses. The measurement models were validated by obtaining estimates of the parameters of the models and by determining whether the model itself provides a good fit to the data (Byrne 2010). Cronbach's alpha was used to measure internal consistency of scales and regression analysis was conducted to test hypotheses.

The compatibility of data obtained via data collection tools was tested via Kurtosis and Skewness test. It is desired to have kurtosis and skewness values between -1 and +1 . However, it is pointed out that values between -2 to +2 would also fall within acceptable limits (Kunnan, 1998; Karaath, 2006). It was observed that the kurtosis scores of those items in the scales were

\footnotetext{
${ }^{3}$ The dat a of the research was obt ained from the third aut hor's master term project.
} 
between 1.433 to -.506 and those of skewness were between -1.233 to -.102 . It can be stated based on this that the data have normal distribution.

\section{FINDINGS}

\subsection{Demographic Data Regarding the Sample}

According to the results obtained (Table 1), most of the participants (104 people) in the survey were employees that do not have executive positions. It is observed that 50 people have been working in the present workplace between 2-5 years. 83 participants were female 60 of whom were between 26-35 years of age. 69 participants were high school graduates.

Table 1: Demographic Data

\begin{tabular}{|c|c|c|c|}
\hline & & $\begin{array}{c}\text { Number } \\
(\mathbf{N})\end{array}$ & $\begin{array}{c}\text { Percentage } \\
(\%)\end{array}$ \\
\hline \multirow{3}{*}{ Position in the Organization } & Top executive & 11 & 7,4 \\
\hline & Mid-level executive & 33 & 22,3 \\
\hline & Employee & 104 & 70,3 \\
\hline \multirow{5}{*}{ Number of Years in the Organization } & $0-1$ & 21 & 14,2 \\
\hline & $2-5$ & 50 & 33,8 \\
\hline & $6-10$ & 38 & 25,7 \\
\hline & $11-20$ & 34 & 23,0 \\
\hline & More than 20 & 5 & 3,4 \\
\hline \multirow{2}{*}{ Gender } & Female & 83 & 56,1 \\
\hline & Male & 65 & 43,9 \\
\hline \multirow{4}{*}{ Age } & Between 18-25 & 29 & 19,6 \\
\hline & Between 26-35 & 60 & 40,5 \\
\hline & Between 36-45 & 47 & 31,8 \\
\hline & More than 45 & 12 & 8,1 \\
\hline \multirow{6}{*}{ Education Level } & Primary School & 22 & 14,9 \\
\hline & High School & 69 & 46,6 \\
\hline & Associate Degree & 22 & 14,9 \\
\hline & Bachelor's Degree & 31 & 20,9 \\
\hline & Master's Degree & 4 & 2,7 \\
\hline & Total & 148 & 100,0 \\
\hline
\end{tabular}

\subsection{Validity and Reliability Analysis}

Confirmatory factor analysis was used to determine the validity of those scales used in the research. Model fits in CFA may be assessed through various goodness-of-fit indices like: chi-square divided by the df value (CMIN/DF), Root Mean Square Residual (RMR), Goodness of Fit Index (GFI), Normed Fit Index (NFI), Incremental Fit Index (IFI) and Comparative Fit Index (CFI). It was determined that 6 items regarding the internal marketing scale decreased the validity according to results supported by exploratory factor analysis as well and those items 
were taken out of the scale. Confirmatory factor analysis was applied once more regarding the internal marketing scale measured by the remaining 9 items. Improvement indexes were examined so that the model would provide better compatibility values and some amendments were made. It was observed that correlating the $6^{\text {th }}$ and $7^{\text {th }}$ and the $8^{\text {th }}$ and $9^{\text {th }}$ items of the scale would pull down the chi square value and that these two correlations would improve the model. The covariance matrices of some observed variables might be balanced in such situations when those correlated items have the same meaning and are used interchangeably. Thus it can be said that one-factor solution for internal marketing scale produced convincing evidence as shown in Table 2. Likewise, it was observed that when first order confirmatory factor analysis was applied on the organizational trust scale, correlation of the $1^{\text {st }}$ and the $2^{\text {nd }}$ as well as the $7^{\text {th }}$ and $8^{\text {th }}$ items of the trust in executive dimension of the scale might improve the model. Therefore after conducting a confirmatory factor analysis on the organizational trust items, it was found that a two-factor solution (trust in the organization and trust in the executive) was consistent with the data. Acceptable model fits and model compatibility indices obtained as a result of confirmatory factor analyses are presented in Table 2. Fit Statistics for CMIN/DF, RMR, GFI, CFI, IFI meets expectations. NFI values, on the other hand, are close to acceptable levels. According to obtained results, it can be expressed that the validity of both scales is ensured.

Table 2: Confirmatory Factor Analysis Results (Goodness of Fit Statistics)

\begin{tabular}{|c|c|c|c|c|c|c|c|c|}
\hline & CMIN & DF & $\begin{array}{l}\text { CMIN/DF } \\
<5\end{array}$ & $\begin{array}{l}\begin{array}{l}\text { RMR } \\
<.08\end{array} \\
\end{array}$ & $\begin{array}{l}\text { GFI } \\
>.85\end{array}$ & $\begin{array}{c}\mathrm{NFI} \\
>.90\end{array}$ & $\begin{array}{l}\text { IFI } \\
>.90\end{array}$ & $\begin{array}{l}\text { CFI } \\
>.90\end{array}$ \\
\hline Internal Marketing & 82.714 & 25 & 3.309 & 0.067 & .889 & .897 & .926 & .925 \\
\hline Organizational Trust & 185.005 & 51 & 3.628 & 0.076 & .823 & .889 & .917 & .916 \\
\hline
\end{tabular}

Reliability coefficients of the scales were calculated via Cronbach's alpha value. The value of .896 was found for internal marketing scale consisting of 9 items. The value of .943 was found for trust in executive dimension of organizational trust consisting of 8 items and for that of trust in organization dimension consisting of 4 items, the value of .949 was calculated. Tezbaşaran (1996) points out that the reliability level foreseen for those measuring tools that might be used in research to be .70 . Therefore, the reliability values of those scales used in the study being above the acceptable limit of .70 asserts the reliability of scales. 


\subsection{Correlation Analysis}

The averages, standard deviations and Pearson correlation coefficients between the variables gathered from the research are presented in Table 3. The factor with the highest average is observed to be trust in the executive while the factor with the lowest standard deviation is internal marketing. If Pearson coefficient which is symbolized with the letter " $r$ " is $r>.70$, the variables can be said to have a "strong relation, if it is $.40<r<.70$, they can be said to have a "medium level relation" (Rumsey, 2011). As presented in the table there is a medium level relation between internal marketing and trust in the executive $(r=-.560 ; p<.01)$ and trust in the organization $(\mathrm{r}=-.553 ; \mathrm{p}<.01)$. There is a strong relation however between the trust in the executive and the trust in the organization $(\mathrm{r}=-.739 ; \mathrm{p}<.01)$.

Table 3: Correlation Analysis Results

\begin{tabular}{llllll}
\hline & Mean & S.D. & $\mathbf{1}$ & $\mathbf{2}$ & $\mathbf{3}$ \\
\cline { 2 - 6 } 1.Internal Marketing & 3.690 & .783 & 1 & & \\
2.Trust in the Executive & 3.929 & 1.003 & $.560^{* *}$ & 1 & \\
3.Trust in the Organization & 3.765 & 1.054 & $.553^{* *}$ & $.739^{* *}$ & 1 \\
\hline$N=148 ; * *$ Correlation is significant at the 0.01 level(2-tailed). & & &
\end{tabular}

Durbin-Watson test was carried out to test whether there were autocorrelation and multicollinearity problems in the research data and the Variance Inflation Factor (VIF) values were utilized. The Durbin-Watson coefficients that were expected to be between 1.5 to 2.5 (Öztürk, 2006:264) were observed to take the value of 1.440 in Model 1 and 1.227 in Model 2. Furthermore, it is stated that VIF values need to be below 10 not to have multicollinearity problem (Hair et al., 2003). The VIF values are found to be below 10 in this study. Therefore, it was concluded that there is no autocorrelation and multicollinearity problem in the data set.

\subsection{Regression Analysis}

Two simple linear regression analyses were carried out to determine the effects of internal marketing on the organizational trust dimensions. In Model 1, the results obtained from the regression analysis towards determining the effect of internal marketing on the trust in the organization factor were presented in Table 4. According to findings obtained internal marketing affects the trust in the organization significantly (St. $\beta=.553 ; p=.000$ ). So the first hypothesis of the study Hypothesis 1 was accepted. Internal marketing explain 30,1\% of total variance in trust in the organization measurements. 
Table 4: The Effect of Internal Marketing on Trust in the Organization

\begin{tabular}{|c|c|c|c|c|c|c|c|}
\hline \multirow{2}{*}{ Model 1} & \multicolumn{2}{|c|}{$\begin{array}{l}\text { Unstandardized } \\
\text { Coefficients }\end{array}$} & \multirow{2}{*}{$\begin{array}{c}\begin{array}{c}\text { Standardized } \\
\text { Coefficients }\end{array} \\
\text { Beta }\end{array}$} & \multirow[t]{2}{*}{$\bar{t}$} & \multirow[t]{2}{*}{ Sig. } & \multirow[t]{2}{*}{$\mathbf{F}$} & \multirow[t]{2}{*}{$\overline{\text { Ad.R }^{2}}$} \\
\hline & B & Std. Error & & & & & \\
\hline Constant & 1.016 & .350 & \multirow[b]{2}{*}{.553} & 2.904 & .004 & \multirow[b]{2}{*}{64.418} & \multirow[b]{2}{*}{.301} \\
\hline \begin{tabular}{|l} 
Internal \\
Marketing
\end{tabular} & .745 & .093 & & 8.026 & .000 & & \\
\hline
\end{tabular}

In Model 2, the effect of internal marketing on the trust in the management was evaluated. As presented in Table 5, it was found that internal marketing significantly affects the trust in the executive (St. $\beta=, 560 ; p=, 000)$. So the second hypothesis of the study Hypothesis 2 was accepted. Internal marketing explain $30,9 \%$ of total variance in trust in manage ment measurements.

Table 5: The Effect of Internal Marketing on Trust in Management

\begin{tabular}{|c|c|c|c|c|c|c|c|}
\hline \multirow{2}{*}{ Model 2} & \multicolumn{2}{|c|}{$\begin{array}{l}\text { Unstandar dized } \\
\text { Coefficients }\end{array}$} & \multirow{2}{*}{$\begin{array}{c}\begin{array}{c}\text { Standardized } \\
\text { Coefficients }\end{array} \\
\text { Beta }\end{array}$} & \multirow[t]{2}{*}{$\mathbf{t}$} & \multirow[t]{2}{*}{ Sig. } & \multirow[t]{2}{*}{$\mathbf{F}$} & \multirow[t]{2}{*}{ Ad. $\mathbf{R}^{2}$} \\
\hline & B & Std. Error & & & & & \\
\hline Constant & 1.280 & .331 & \multirow[b]{2}{*}{.560} & \begin{tabular}{|l|l|}
3.864 \\
\end{tabular} & .000 & \multirow[b]{2}{*}{66.813} & \multirow[b]{2}{*}{.309} \\
\hline \begin{tabular}{|l|} 
Internal \\
Marketing
\end{tabular} & .718 & .088 & & 8.174 & .000 & & \\
\hline
\end{tabular}

\section{CONCLUSIONS AND FUTURE RESEARCH DIRECTIONS}

This study investigated how internal marketing would affect the factors of organizational trust. Two hypotheses compatible with the literature were both accepted in the study. According to findings, internal marketing affects the trust in the executive positively, i.e. those organizations with executives that believe external customer satisfaction goes through internal customer satisfaction make their employees have more trust. While people are forming trust towards people they have a relation, they do this according to various events and phenomena. Behaviors and attitudes and social relations play an important role increasing the trust individuals feel towards each other. According to findings obtained from the study, the trust towards the executives that give value to their employees, that provide their vision development and that reward them within the activities of internal marketing is higher. One of the purposes of internal marketing practices is to increase the intra-organizational communication (Kandampully, 2006; Lings and Greenley, 2005; Rafiq and Pervaiz, 2000). It 
is a natural consequence that the trust in the executive increases when s/he has active communication with employees, understands and listens to them, answers their demands and provides the opportunity to let the parties get to know each other via communication. It is much easier for those parties who build communication, get to know each other and decrease the obscurities towards each other to trust each other.

A great deal of attention is paid to the personal development of employees in internal marketing. Personal development refers to the training of employees and provision of their needs to provide them to adapt to changing internal and external environment and achieve a better future point. In organizations operating with this management philosophy, the role of the managers is to support employees for personal development and motivate them. In the concept of internal marketing, it is important to provide integration of all functions and operations with mutual trust. By this way, employees' personal confidence increases against managers who invest in employees' own personal development.

On the other hand, the main purpose of the internal marketing concept is stated to encourage the employees feel that the executives take them and their needs seriously (Candan and Çekmecelioğlu, 2009). In cases where the perception is formed that the executive level takes the employees into consideration, it is observed that the employees had higher trust in the executives. It will be easier for the employees to satisfy the customers in those organizations where there is trust in the executives. Both internal and external needs of employees are taken into consideration in internal marketing practices targeting to enhance the motivation of employees. It is predicted that the employees that think the management cares for them have positive feelings based on trust towards their executives. Executives have the role to provide coordination and integration between functions within the scope of internal marketing activities (Rafiq and Pervaiz, 2000:449). It is observed that trust might increase coordination (Vlaar et al., 2007) just like coordination might increase trust. It can be stated that those executives who increase the positive relations and cooperation among departments, encourage employees and executives to integrate, put an emphasis on team spirit might create positive feelings among employees and therefore allow the decisions and practices that are internal marketing oriented to trigger the building of trust in executives.

Besides trust in the executive, the trust perception in general towards the organization is also affected by internal marketing. According to Kanter (1993), those work environments that ease access to information and resources, encourage their employees and pay attention to the development of employees increase organizational trust. It is observed that one of the 
biggest needs of employees ensuring organizational trust in organizational environments is providing such an environment. An organization is one of the places where individuals spend most of their time during the day, maybe the most important. So it can be understood that besides physical security, individuals need a lot of psychological security in the organizations. Internal marketing is observed to be one of the most important ways to gain the trust of its employees for the organization. Trust towards the organization is very important for the employees. Like individuals organizations also have an identity and personality. When there is a trust in this personality, the mistakes that the executives make may not have consequences for the entire organization, some of the pressures from higher executives might be tolerated and more effort might be shown for the performance of the organization as a whole. Concerning these points, it is observed that trust in the executive and trust in the organization diversify from each other. So it can be stated that it is necessary to increase the trust in both the organization and the executive via internal marketing practices. On the other hand, it is observed that the concepts trust in the organization and trust in the executive support each other, i.e. when employees feel trust towards their executives, their trust towards their organization also increases. Similarly, the more employees trust the organization the more they have the tendency to trust the executives as well. However, the distrust in any would most probably spread to the other. Depending on all these findings, it is suggested to the executives of the organization to increase the quality in internal marketing practices to try affecting the trust feelings of employees positively.

Besides important findings that contribute to literature, as in other studies, this study also has some limitations. Due to time limitations only a small sample was analyzed. More healthy results might be achieved via bigger samples. Furthermore, if further studies are carried out on the employees of a different sector besides the tourism sector and in different countries, more generalizable results might be gathered. For further studies it is suggested to investigate how internal marketing would affect the trust in colleagues and lack of trust in the organization. It would be appropriate to add some other variables to future research models that did not exist in the present research model. 


\section{REFERENCES}

Ay, C. and Kartal, B. (2003), “İçsel pazarlama: Literatür incelemesi”, Öneri Dergisi, 5 (20), 15-25.

Berry, L. L., Hensel, J. S., and Burke M. C. (1976), "Improving retailer capability for effective consumerism response", Journal of Retailing, 52(3), 3-14.

Berry, L.L. and Parasuraman, A. (1991), Marketing Services: Competing through Quality, The Free Press, New York, NY.

Byrne, Barbara M. (2010), Structural equation modeling with AMOS: Basic concepts, applications and programming (2nd ed.). Mahwah, NJ: Lawrence Erlbaum Associates.

Bromiley, P. and Cummings L. L. (1996), The Organizational Trust Inventory (OTI). Roderick M. Kramer ve Tom R. Tyler, Trust in Organizations: Thous and Oaks: Sage, pp. 302-319.

Candan, B. and Cekmecelioğlu, H. G. (2009), "A Research On The Effect Of Internal Marketing On Dimensions Of Organizational Commitment”, Yönetim, 20 (63), 41-58.

Demircan, N. and Ceylan, A. (2003), “Örgütsel Güven Kavramı: Nedenleri ve Sonuçları”, Yönetim ve Ekonomi, 10 (2), 139-150.

Foreman, S. K. and Money, A. H. (1995), “Internal Marketing: Concepts, Measurements and Application”, Journal of Marketing Management, 11(8), 755 - 768.

George, W. R. (1977), “The retailing of services a challenging future”, Journal Retail, 53 (3), 85-98.

Gülşen, G. (2010), Bankalarda İçsel Pazarlama Çalışmaları Ve Kamu Bankalarıla Özel Bankaların Karşılaştırılması, Unpublished master's thesis, Dumlupınar University, Kütahya, Turkey.

Hair, J. F. Jr., Bush, R. P. and Ortinau, D. J. (2003), Marketing Research: Within a Changing Information Environment, The McGraw-Hill/Irwin, Second Editon.

Hosmer, L. T. (1995), "Trust: the connecting link between organizational theory and philosophical ethics", Academy of Management Review, 20(2), 379-403.

Hume, C. and Hume, M. (2015), "The critical role of internal marketing in knowledge management in not-forprofit organizations", Journal of Nonprofit \& Public Sector Marketing, 27(1), 23-47.

İçli, E.T and Aslan, F.E. (2012), "The Effect of Internal Marketing on the Dimensions of Organizational Commitment: A Research on Nurses in Turkey”, Hemşirelikte Araştırma Geliştirme Dergisi, 14(3), 3952.

Johnston, M.W., Parasuraman, A., Futtrell, C.M., and Black, W.C. (1990), “A longitudinal assessment of the impact of selected organisational influences on salespeople's organisational commitment during early employment", Journal of Marketing Research, 27 (3), 333-344. 
Kaçaroğlu, M. O. (2015), Hizmet İşletmelerinde İçsel Pazarlama Ve Hizmet Kalitesinin Karşılaştırmalı Değerlendirilmesi: Pamukkale Üniversitesi Spor Merkezi Örneği, Unpublished master's thesis, Pamukkale University, Denizli, Turkey.

Kalyoncu, H. (2007), Hizmet Sektöründe Müşteri Tatmini Açısından İçsel Pazarlama Ve Uygulama, Unpublished master's thesis, Dokuz Eylül University, İzmir, Turkey.

Kandampully, J. (2006), Services Management: The New Paradigm in Hospitality, Pearson Education, Australia.

Kanter, R. M. (1993), Men and Women of the Corporation, New York: Basic Books.

Karaatlı, M. (2006), Verilerin Düzenlenmesi ve Gösterimi, SPSS Uygulamalı Çok Değişkenli İstatistik Teknikleri, (Ed.: Şeref Kalaycı), Second Edition, Asil Yayın Dağıtım, Ankara, Turkey.

Kelemen, M. and Papasolomou-Doukakis, I. (2004), "Can culture be changed? A study of internal marketing", The Service Industries Journal, 24 (5),121-135.

Kırbaşlar, M. (2013), Çalışanların Etik İklim Algılarının, ÖrgütselGüven Algısı Ve Üretkenlik Karşıtı Davranışlar İle İlişkilerinin İncelenmesine Yönelik Bir Araştırma, Unpublished master's thesis, İstanbul University, İstanbul, Turkey.

Kunnan, A. J. (1998), “An Introduction to Structural Equation Modelling for Language Assessment Research”, Language Testing, 15(3), 295-332.

Lings, I.N. and Greenley, G.E. (2005), "Measuring internal market orientation”, Journal of Service Research, 7 (3), 290-305.

Mishra, J. and Morrissey, M.A. (1990), “Trust in Employee/Employer Relationships: A Survey of West Michigan Managers", Public Personnel Management, 19 (4), 443-485.

Nevin, J. R. (1995). "Relationship Marketing and Distribution Channels: Exploring fundamental Issues", Journal of Academy of Marketing Science, 23(4), 327-335.

Ng, E., Fang, W. T., and Lien, C. Y. (2016). “An empirical investigation of the impact of commitment and trust on internal marketing”, Journal of Relationship Marketing, 15(1-2), 35-53.

Nyhan, R. C. and Marlowe, H. A. (1997), "Development and psychometric properties of the organizational trust inventory”, Evaluation Review, 21(5), 614-635.

Odabaş1, Y. (1995), Pazarlama iletişimi, Eskişehir: Anadolu University Press, No.851.

Özkalp, E. and Kırel, Ç. (2010), Örgütsel Davranış, 4. Edition, Ekin Basın Yayın Dağıtım, Bursa.

Öztürk, E. (2006), Çoklu Doğrusal Regresyon Modeli, SPSS Uygulamalı Çok Değişkenli İstatistik Teknikleri, (Ed.: Şeref Kalayc1), Asil Yayın Dağıtım, Ankara, Turkey. 
Rafiq, M. and Pervaiz K. A. (2000), "Advances in the internal marketing concept: definition, synthesis and extension", Journal of Services Marketing, 14(6), 449-462.

Reinke, S. J. and Baldwin J.N. (2001), "Is Anybody Listening? Performance Evaluation Feedback in the U.S. Air Force", Journal of Political and Military Sociology, 29(1), 160-176.

Rumsey, D. J. (2011), Statistics for dummies, John Wiley \& Sons.

Sasser, W. E. and Arbeit, S. P. (1976), “Selling jobs in the service sector”, Business horizons, 19 (3), 61-65.

Scovotti, C. and J. W. Peltier. (2005), "Participant Satisfaction with the Vocational Rehabilitation Process: A Micro Perspective of Relationship Dimensions", Health Marketing Quarterly, 22 (4),3-26.

Tezbaşaran, A. A. (1996), Likert Tipi Ölçek Geliştirme Kılavuzu, Türk Psikologlar Derneği Yayınları, Ankara, Turkey.

Tüzün, İ. K. (2007), “Güven, Örgütsel Güven ve Örgütsel Güven Modelleri”, Karamanoğlu Mehmetbey Üniversitesi Sosyal Ve Ekonomik Araştırmalar Dergisi, 5, 93-118.

Uslu, O. (2013), Güç Mesafesi Algısının Örgütsel Güvene Etkisi: Bir Devlet Üniversitesi Örneği, Unpublished master's thesis, Sakarya University, Sakarya, Turkey.

Üstün F. (2015), Örgütlerde sıkılık-esneklik boyutunun örgütsel güven, kurumsal girişimcilik ve firma performansına etkisi: Türkiye'nin öncü sanayi işletmeleri üzerine bir araştırma, Unpublished doctoral dissertation, Çukurova University, Adana, Turkey.

Vlaar, P. W., Van den Bosch, F. A. and Volberda, H. W. (2007), "On the evolution of trust, distrust, and formal coordination and control in interorganizational relationships: Toward an integrative framework", Group \& Organization Management, 32 (4), 407-428.

Yapraklı, Ş. and Özer, S. (2002), İçsel Pazarlama: Erzurum'da Faaliyet Gösteren Zincir Perakendeci Mağazacıların Çalı̧̧anları Üzerinde Bir Alan Araştırması, in 7.Ulusal Pazarlama Kongresi Bildirileri, Afyon Kocatepe University, pp.43-60, Afyon, Turkey.

Yilmaz, A. and Atalay, C. G. (2009), “A Theoretical Analyze On The Concept of Trust In Organisational Life”, European Journal of Social Sciences, 8(2), 341-352. 